\title{
Localization of Cadmium in the Viscera and the Muscular Tissues of Carnivorous Gastropods before and after Exposure
}

\author{
Kunio Ikuta*1 \\ (Accepted August 7, 1987)
}

\begin{abstract}
Ivory shells and Pfeffer's whelks were exposed to $10 \mu \mathrm{g} / l$ of cadmium for 20 days, and distribution rates and localization indices of the controls were compared to those of the exposure groups, respectively.

In ivory shells, distribution rates in the viscera decreased from more than $99 \%$ in the control to $c a .96 \%$ in the exposure group, and consequently, the rates in the muscular tissues increased from nearly $1 \%$ to $c a .4 \%$, respectively. In Pfeffer's whelks, distribution rates of the control were $c a$. $85 \%$ in the viscera and ca. $15 \%$ in the muscular tissues, while the rates of the exposure groups were $c a .67 \%$ in the viscera and $c a .33 \%$ in the muscular tissues.

Extremely low values of $i$-LI were found in the muscular tissues of the ivory shells with $c a$. -82 in the control, and the values weakened up to $c a .-18$ in the exposure groups. The $i-\mathrm{LI}$ values for the viscera were quite similar in the control (2.28) and the exposure groups (2.19).

In the Pfeffer's whelks the values of $i$-LI in the muscular tissues weakened from -4.30 in the control to -1.48 in the exposure group, while in the viscera the values were substantially similar, 1.93 in the control and 1.33 in the exposure group.

These results were similar to those obtained previously in the herbivorous gastropods, Haliotis discus and Batillus cornutus exposed to cadmium.

As shown from the results on localization index of cadmium in the muscular tissues, when gastropod mollusks were exposed to enhanced concentrations of the metal, in shallow water environments, the $i$ - LI values of cadmium in the muscular tissues can vary from negatively high to relatively low values.
\end{abstract}

Distribution and localization of heavy metals in the -viscera and the muscular tissues were documented by Ikuta ${ }^{1,2)}$ for the herbivorous gastropods, Batillus cornutus and Haliotis discus. He revealed that distribution rates and $i$-LI values of cadmium in the muscular tissues of these specimens varied greatly before and after the exposure. These results have been obtained only for the herbivorous species. As well as the herbivorous gastropods, $B$. cornutus, $H$. discus, etc. the carnivores such as muricids, buccinids, fasciolariids, etc. also important as marine food resources. Buccinids are useful as experimental specimens for heavy metal accumulation studies, since they are living in shallow waters, caught by fisherman fisheries for marine food and reared easily in laboratory. Therefore, an ivory shell Babylonia japonica and a Pfeffer's whelk Siphonalia pfefferi belonging to the Buccinidae were chosen as experimental specimens in order to compare the localization trends in them with those of the herbivorous gastropods, B. cornutus $^{1)}$ and $H$. discus. ${ }^{2)}$
Hence, the investigation was planned to make clear the distribution and localization of cadmium in the viscera and the muscular tissues of an ivory shell and a Pfeffer's whelk as representatives of carnivorous gastropods. The localization trends of the carnivores examined in this study were compared with those of the two herbivores. ${ }^{1,2)}$ Moreover, the $i$-LI value of cadmium in muscular tissues was proposed as an indicator for the metal pollution in shallow water environments.

\section{Materials and Methods}

In ivory shells, weights in grams of viscera ranged from 9.37 to 12.81 and those of muscular tissues ranged from 15.31 to 19.20 grams. On the other hand, in Pfeffer's whelk, the former weights ranged between 0.25 and 0.32 , and the latter between 0.49 and 0.57 .

Sixty-three individuals of ivory shells divided into six groups were reared in $30 \mathrm{l}$ 's of seawaters with a ratio of soft body weight in gram to

*1 Laboratory of Aquatic Environment and Ecology, Department of Fisheries, Faculty of Agriculture, Miyazaki University, Miyazaki 889-21, Japan (生田國雄：宮崎大学農学部). 
water volume in liter, 12.9, and seven hundred and eighty of Pfeffer's whelks divided into six groups were held in $10 l$ 's of seawaters with a ratio of soft body weight in gram to water volume in litre, 9.60. Rearing seawaters of the two species were renewed at the regular intervals of $48 \mathrm{~h}$ throughout the experiments.

The original concentration of cadmium in stock seawater for rearing was $0.02 \mu \mathrm{g} / l$, which was determined from 5 liters of seawater by the method $^{1)}$ mentioned priviously. Preliminarily, variations of cadmium concentrations added in rearing seawater by $10 \mu \mathrm{g} / l$ was tested under a condition free from experimental specimens. Concentrations of cadmium determined at $0,3,6$, $12,24,48$ and 72 hours indicated $9.2 \pm 0.24 \mu \mathrm{g} / \mathrm{l}$ (8.8, minimum to 9.2 , maximum) under water temperature of $25.01 \pm 0.57^{\circ} \mathrm{C}$ and similar values to specific gravity described below.

Specimens of the two species were exposed to $10 \mu \mathrm{g} / \mathrm{l}$ of cadmium for 20 days under water temperatures of $25.6 \pm 0.60^{\circ} \mathrm{C}$ and specific gravities of $1.0238 \pm 0.0009\left(15^{\circ} \mathrm{C}\right)$ for ivory shells, and $21.2 \pm$ 1.10 and $1.0244 \pm 0.0009$ for Pfeffer's whelks, respectively. These temperatures and specific gravities were almost equal to those of the shallow water environments in which they lived when the exposure experiments were performed. The implication of exposure concentration ${ }^{1-3)}$ and the preparation of stock solution for cadmium ${ }^{2)}$ were explained previously.

Flesh meats of a Japanese littleneck clam
Ruditapes philippinarum were laid by 1 to $2 \mathrm{~g}$ in the rearing aquaria as feed every evening, and rearing waters were exchanged every morning. Cadmium in the meat was not detected.

Just before the experiment (the control) and at the cessation of exposure (the exposure group), the specimens were dissected into the two compartments, the viscera(digestive diverticula, gonads, circulatory and digestive systems, etc.) and the muscular tissues (foot, columellar muscle, and free edge of mantle). Cadmium concentrations in the viscera and the muscular tissues of the specimens before and after the exposure were determined by atomic absorption spectrophotometry following wet-digestion with a mixture of nitric and perchloric acids and represented by $\mu \mathrm{g} / \mathrm{g}$ fresh wt.

Distribution rates of the metal in percentage were calculated from absolute amounts in the viscera (or the muscular tissues) divided by sums of absolute amounts in the two compartments. Localization trends were discussed with induced Localization Indices ${ }^{22}$ obtained by subtracting ratios of the viscera (or the muscular tissues) weight percentages in whole soft bodies to distribution rates of cadmium in the viscera (or the muscular tissues) from their reciprocals.

\section{Results and Discussion}

Accumulation Amounts of Cadmium in the Two Compartments of the Two Species

Table 1. Cadmium concentrations in the viscera and the muscular tissues of the two species of the control and the exposure groups

\begin{tabular}{|c|c|c|c|c|}
\hline \multirow{2}{*}{$\begin{array}{l}\text { Experimental } \\
\text { group }\end{array}$} & \multicolumn{2}{|c|}{ B. japonica } & \multicolumn{2}{|c|}{ S. pfefferi } \\
\hline & VP & MP & VP & $\mathrm{MP}$ \\
\hline \multirow[t]{5}{*}{ Control } & 11.36 & 0.06 & 1.63 & 0.20 \\
\hline & 18.22 & 0.09 & 2.11 & 0.20 \\
\hline & 14.86 & 0.06 & 2.61 & 0.19 \\
\hline & 22.94 & 0.10 & 1.46 & 0.20 \\
\hline & 21.48 & 0.10 & 2.40 & 0.17 \\
\hline (m. $\pm \mathrm{s} . \mathrm{d})$. & $17.77 \pm 4.75$ & $0.08 \pm 0.02$ & $2.04 \pm 0.49$ & $0.19 \pm 0.01$ \\
\hline \multirow[t]{6}{*}{ Exposure } & $25.50 \pm 4.78$ & $0.44 \pm 0.04$ & $9.71 \pm 0.36$ & $1.94 \pm 0.14$ \\
\hline & $20.01 \pm 5.27$ & $0.41 \pm 0.04$ & $9.24 \pm 0.48$ & $2.35 \pm 0.20$ \\
\hline & $19.20 \pm 3.86$ & $0.54 \pm 0.04$ & $8.53 \pm 0.06$ & $2.75 \pm 0.17$ \\
\hline & $18.05 \pm 8.50$ & $0.66 \pm 0.25$ & $7.18 \pm 0.20$ & $2.44 \pm 0.10$ \\
\hline & $21.75 \pm 2.16$ & $0.45 \pm 0.06$ & $6.86 \pm 0.50$ & $1.87 \pm 0.10$ \\
\hline & $28.57 \pm 13.48$ & $0.50 \pm 0.06$ & $5.93 \pm 0.27$ & $1.57 \pm 0.18$ \\
\hline (m. \pm s.d.) & $22.18 \pm 7.26$ & $0.50 \pm 0.13$ & $7.91 \pm 1.42$ & $2.15 \pm 0.43$ \\
\hline
\end{tabular}

Note: Visceral and muscular parts were abbreviated to VP and MP. Concentration unit was indicated as ppm on a fresh weight basis. 
Cadmium concentrations of the two compartments in the two species were given in Table 1, being separated into the control and the exposure groups. In the control, five analytical groups comprising an individual for ivory shells and for Pfeffer's whelks five analytical groups comprising ten individuals were prepared. In the exposure groups, six groups were prepared for analyses, being consisted of three groups including three individuals for ivory shells and including thirty individuals for Pfeffer's whelks.

In ivory shell, the metal concentrations of the viscera were slightly raised in the exposed specimens when compared to those of the control, and in the muscular tissues the concentrations were about 6 times higher in the exposure groups than the control. In Pfeffer's whelks, on the other hand, the significant increments of the metal in the two compartments were recognized in the exposure groups, with about 4 (for the viscera) and 11 (for the muscular tissues) times higher levels than those of the control. Thus, except for the viscera in ivory shells which the metal contents were slightly higher in the exposure groups than the control, the concentrations were raised significantly in the others at the end of exposure (Table 1).

Inter-species differences in the metal concentrations in the two compartments were recognized as follows: in the viscera the concentrations were higher in ivory shells than Pfeffer's whelks irrespective of whether or not they were exposed to metal, and in the muscular tissues these relationships reversed (Table 1).

\section{Distribution Rates and $i-L I$ Values of the Two Compartments in Controls and Exposure Groups}

Changes in distribution rates $(\%)$ and values of $i-\mathrm{LI}$ are given in Table 2 . Slightly more than $99 \%$ of cadmium was distributed in the viscera and consequently, nearly $1 \%$ in the muscular tissues of ivory shells in the control. On the other hand, about $85 \%$ of the metal was distributed in the viscera and consequently about $15 \%$ in the muscular tissues of Pfeffer's whelks in the control. Thus, there were clear differences between the rates of the two compartments of the two species, respectively. On account of the above-mentioned differences in distribution rates, the values of $i$-LI differed between the two compartments of the two species, especially in the muscular tissues. After the exposure, the distribution rates decreased in the viscera of the two species, especially in that of Pfeffer's whelks with a large difference in the rates between the control and the exposure groups. But, the ratio (control/exposure) of $i$-LI value obtained in the controls to that in the exposure groups of the muscular tissues was higher in ivory

Table 2. Distribution rates $(\%)$ and values of the $i$-LI of viscera and the muscular tissues of $B$. japonica and $S$. pfefferi in the control and the exposure groups

\begin{tabular}{|c|c|c|c|c|c|c|c|c|}
\hline \multirow{3}{*}{ Species } & \multicolumn{4}{|c|}{ Control } & \multicolumn{4}{|c|}{ Exposure } \\
\hline & \multicolumn{2}{|c|}{ DR $(\%)$} & \multicolumn{2}{|c|}{$i-\mathrm{LI}$} & \multicolumn{2}{|c|}{$\mathrm{DR}(\%)$} & \multicolumn{2}{|c|}{$i-\mathrm{LI}$} \\
\hline & VP & MP & VP & MP & VP & MP & VP & MP \\
\hline \multirow{6}{*}{ B. japonica } & 99.12 & 0.88 & 2.28 & -71.36 & 97.18 & 2.82 & 2.22 & -22.19 \\
\hline & 99.18 & 0.82 & 2.28 & -71.26 & 96.70 & 3.30 & 2.21 & -18.92 \\
\hline & 99.33 & 0.67 & 2.28 & -93.16 & 95.48 & 4.52 & 2.17 & -13.81 \\
\hline & 99.27 & 0.73 & 2.28 & -86.33 & 94.23 & 5.77 & 2.13 & -10.79 \\
\hline & 99.23 & 0.77 & 2.28 & -80.87 & 96.64 & 3.36 & 2.21 & -18.60 \\
\hline & & & & & 97.15 & 2.85 & 2.22 & -21.94 \\
\hline $\begin{array}{l}\text { mean } \\
\pm \text { s.d. }\end{array}$ & $\begin{array}{r}99.23 \\
\pm 0.08 \\
\end{array}$ & $\begin{array}{r}0.77 \\
\pm 0.08 \\
\end{array}$ & $\begin{array}{r}2.28 \\
+0.00 \\
\end{array}$ & $\begin{array}{r}-81.60 \\
\pm 8.51 \\
\end{array}$ & $\begin{array}{r}96.23 \\
\pm 1.16 \\
\end{array}$ & $\begin{array}{r}3.77 \\
\pm 1.16 \\
\end{array}$ & $\begin{array}{r}2.19 \\
\pm 0.04\end{array}$ & $\begin{array}{r}-17.70 \\
\pm 4.54\end{array}$ \\
\hline \multirow{6}{*}{$S$, pfefferi } & 82.18 & 17.82 & 1.83 & -3.31 & 73.82 & 26.18 & 1.56 & -2.03 \\
\hline & 85.66 & 14.34 & 1.95 & -4.23 & 68.98 & 31.02 & 1.39 & -1.58 \\
\hline & 88.60 & 11.40 & 2.04 & -5.43 & 63.65 & 36.35 & 1.20 & -1.19 \\
\hline & 80.51 & 19.49 & 1.78 & -2.97 & 62.46 & 37.54 & 1.15 & -1.12 \\
\hline & 88.88 & 11.12 & 2.05 & -5.57 & 67.48 & 32.52 & 1.34 & -1.46 \\
\hline & & & & & 68.11 & 31.89 & 1.36 & -1.51 \\
\hline $\begin{array}{l}\text { mean } \\
\pm \text { s.d. }\end{array}$ & $\begin{array}{r}85.17 \\
\pm 3.76\end{array}$ & $\begin{array}{r}14.77 \\
\pm 3.83\end{array}$ & $\begin{array}{r}1.93 \\
\pm 0.12\end{array}$ & $\begin{array}{r}-4.30 \\
\pm 1.19\end{array}$ & $\begin{array}{r}67.42 \\
\pm 4.07 \\
\end{array}$ & $\begin{array}{r}32.58 \\
\pm 4.07\end{array}$ & $\begin{array}{r}1.33 \\
\pm 0.15\end{array}$ & $\begin{array}{r}-1.48 \\
\pm 0.32\end{array}$ \\
\hline
\end{tabular}

Note: Distribution rates in the visceral and the muscular parts were abbreviated to $D R$. 
shells (4.62 on average) than Pfeffer's whelks (2.91 on average). The metal was highly negatively localized in the muscular tissues of ivory shells in the control with $c a .-82$ of $i$-LI value, and differed greatly from that $(-4.30)$ of Pfeffer's whelks.

Utility of Localization Index of the Muscular Tissues in Gastropods for Cadmium Pollution

In the muscular tissues of the two species, the $i$-LI values increased at the end of exposure with the ratios of 4.61 for ivory shells and 2.91 for Pfeffer's whelks when compared with initial values. Even though the variations of $i$-LI values was restricted in the range of the negative direction as shown in Table 2, the degrees of increases in the muscular tissues were extremely high compared to those of the decrease in viscera of the two species. Ikuta demonstrated similar depressions in the values of $i$-LI's in the viscera of $B$. cornutus $^{1)}$ and $H$. discus. ${ }^{2)}$ The similarity in ascending tendency of $i-\mathrm{LI}$ of muscular tissues occurred irrespective of species with different feeding habits, with concentration gradients of cadmium and with duration of exposure to the metal. Therefore, it can be inferred that such phenomenon is common to all marine gastropod species, and that the ascending tendency is related to the degree of metal pollution, and that the $i$-LI value of the muscular tissues in gastropods inhabiting shallow water environments is recommended as a proper indicator of the metal pollution.
As shown from the results on the localization index of cadmium in the muscular tissues of the four species $B$. cornutus, $H$. discus, B. japonica and $S$. pfefferi, when gastropod mollusks were exposed to enhanced concentrations of the metal in shallow water environments, the $i$-LI values of cadmium in the muscular tissues can vary from negatively high to relatively low figures. If the $i-\mathrm{LI}$ value in the muscular tissues is found to be zero or positive, it may be decided that the specimen is grossly contaminated with the metal.

\section{Acknowledgements}

The author wishes to express deepest appreciation to Dr. Joseph W. Rachlin, Professor of City University of New York, for his valuable review in the preparation of the manuscript and to Dr. K. Itoh, Associate Professor of Miyazaki University, for his useful criticism and advice.

\section{References}

1) K. Ikuta: Nippon Suisan Gakkaishi, 53, 12371242 (1987).

2) K. Ikuta: Nippon Suisan Gakkaishi, 53, 22672272 (1987).

3) U. Förstner and G.T.W. Wittmann: Metal Pollution in the Aquatic Environment, SpringerVerlag, Berlin Hidelberg, 1979, pp. 26-30. 